\title{
Astigmatism treatment during phacoemulsification: a review of current surgical strategies and their rationale
}

\section{Tratamento do astigmatismo por ocasião da facoemulsificação: revisão e embasamento das estratégias cirúrgicas atuais}

Giuliano de Oliveira Freitas ${ }^{1}$, Joel Edmur Boteon², Mario José Carvalho ${ }^{3}$, Rogerio de Melo Costa Pinto ${ }^{4}$

\begin{abstract}
Preexisting corneal astigmatism, present at the time of cataract surgery, is reviewed in detail throughout this article on its most important aspects such as occurrence rates, clinical relevance and current treatment options. Special emphasis is given to the latter aspect. Each method's rationale, advantage and limitation ishigh lightened. Comparisons between treatment options, whenever possible, are also provided.
\end{abstract}

Keywords: Astigmatism/surgery; Cataract/complications; Phacoemulsification/methods; Lens implantation, intraocular

\section{ReSUMO}

O astigmatismo corneano pré-existente, por ocasião da cirurgia de catarata, é detalhadamente revisado neste artigo sob aspectos tais como: ocorrência, relevância clínica com ênfase nas opções de tratamento atualmente disponíveis. Destacamos o embasamento teórico de cada método, bem como vantagens e limitações foram destacadas. Comparações entre as opções terapêuticas, sempre que possível, são apresentadas.

Descritores: Astigmatismo/cirurgia; Catarata/complicações; Facoemulsificação/métodos; Implantação de lentes intraoculares

\footnotetext{
${ }^{1}$ ResearchFellow, Universidade Federal de Minas Gerais, Belo Horizonte (MG), Brazil; Staff of Cataract Surgery Department, Instituto de Saúde Ocular, Uberlândia (MG), Brazil;

${ }^{2}$ Ophthalmology Professor, Universidade Federal de Minas Gerais, Belo Horizonte (MG), Brazil.

${ }^{3}$ Head of Cataract Surgery Department, Instituto de Saúde Ocular, Uberlândia (MG), Brazil;

${ }^{4}$ Biostatistics Professor, Universidade Federal de Uberlândia, Uberlândia (MG), Brazil.
}

The authors declare no conflicts of interest

Recebido para publicação em 27/2/2013 - Aceito para publicação em 6/10/2013 


\section{INTRODUCTION}

$\mathbf{C}$ ataract surgery has evolved over the past few years with new surgical techniques, devices and improvements in the design of intraocular lenses, shifting from traditional spheric-monofocal lenses to aspheric, toric, pseudoaccomodative, accomodative or a combination of these features ${ }^{(1,2)}$. It is, currently, among the most performed planned surgical procedures worldwide, positively impacting over patients' quality of life ${ }^{(3,4)}$.

Astigmatism is a visually disabling refractive error affecting the general population, especially those with cataracts ${ }^{(2)}$.With increased patients' expectations, the trend is not only to remove the cataract, but also to address the problem of pre existing astigmatism at the time of phacoemulsification. In addition to being a therapeutic procedure, cataract surgery is currently considered as a surgical approach for refractive errors ${ }^{(5)}$. The amount of techniques available to correct astigmatism during phacoemulsification suggests that the issue of astigmatism treatment by the time of phacoemulsification is currently under debate ${ }^{(6)}$.

\section{Methods}

PubMed and SciELO were searched on february $22^{\text {nd }} 2013$ using search words astigmatism and phacoemulsification. Retrieved references with no abstracts were not considered. This initial search retrieved 896 abstracts in english, portuguese or spanish, published from 1993 to 2013. Fifty-eight relevant references, concerning pre existing corneal astigmatism or surgically induced astigmatism, were, thus, obtained and reviewed in detail.

\section{$\underline{\text { ResULTS }}$}

\section{Definition of astigmatism}

In an optimal stigmatic (point-like) optical system, a point in the object space is focused as a point image. The shape of the blurred image, for out-of-focus point objects, is always a circle.

An astigmatic optical system is nonpoint-like. In a regular astigmatic optical system an object point is focused as two mutually perpendicular line segments delimiting an intermediate interval, termed Sturm's conoid. No point focus is formed, but the blurred image attains different shapes and directions in Sturm's interval. The focal lines define the orthogonal principal meridians of the conoid. Differential magnification in the principal meridians means that the focal line segments have different lengths. Irregular astigmatism is the non-stigmatic and non-regular astigmatic part of the refractive spectrum. In wave-front analysis, stigmatic and regular astigmatic powers - correctable by spherocylinders- are termed lower-order aberrations. Irregular astigmatic elements are called higher-order aberrations ${ }^{(7)}$.

\section{Prevalence of astigmatism}

A significant number of patients having cataract surgery have a degree of pre existing corneal astigmatism ${ }^{(8-11)}$. Estimates of the incidence of significant, naturally occurring astigmatism vary widely from $7.5 \%$ to $75 \%{ }^{(11-13)}$. In a study comprising 4540 eyes in 2415 patients. Figure 1 is a histogram with frequency distribution of corneal astigmatism values for the entire sample showing that $13.2 \%$ of eyes did not present corneal astigmatism, $64.6 \%$ had corneal astigmatism between 0.25 and $1.25 \mathrm{D}$, and $22.2 \%$ had astigmatism of $1.50 \mathrm{D}$ or higher ${ }^{(9)}$.

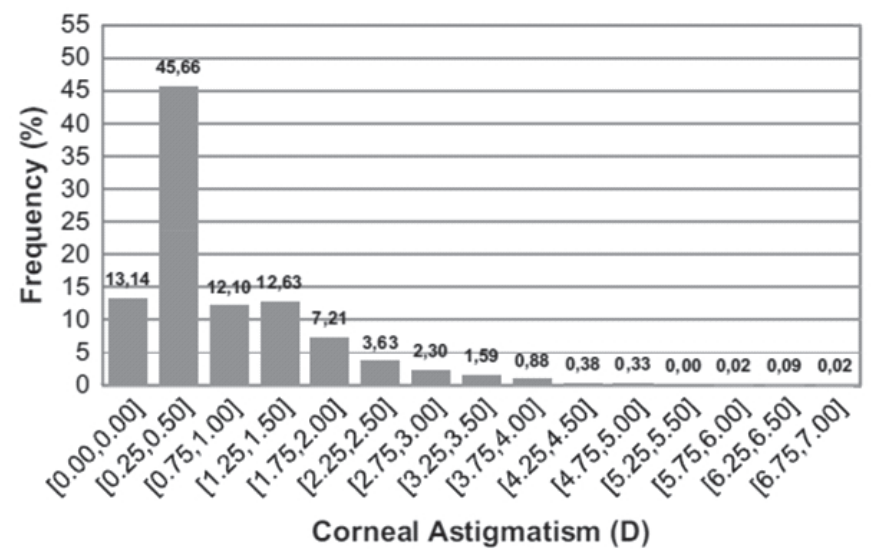

Figure 1: Histogram of the corneal astigmatism distribution in the entire sample (4540 eyes) ${ }^{(9)}$

\section{Classification of corneal astigmatism magnitudes}

Corneal astigmatism power may be considered as mild up to $1.00 \mathrm{D}$. Moderate, for magnitudes between $1.0 \mathrm{D}$ and $2.00 \mathrm{D}$, or highly astigmatic if equals to, or greater than the upper limit of $2.00 \mathrm{D}^{(14)}$.

\section{Astigmatism analysis}

Meaningful analysis of astigmatic data is essential to understanding the results of refractive and cataract surgical procedures. Certain elements of astigmatic analysis are simple and straightforward, but other aspects can be extraordinarily complex. Several investigators have developed elaborate methods of further describing and characterizing astigmatic change. Such methods may exhibit marked differences among each other ${ }^{(15)}$ :

Alpins and coworkers ${ }^{(16-19)}$ use vector analysis to generate various indices to more fully describe astigmatic outcomes. Many of these indices, such as difference vector, index of success and coefficient of adjustment, provide remarkably useful and intuitive means of understanding the effects of the surgery.

Thibos and coworkers ${ }^{(20-21)}$ take another approach to analyzing astigmatic data. This method separates refractive data into 3 power vectors: spherical equivalent and 2 Jackson crossed cylinders separated by 45 degrees. With these, they can demonstrate analysis of the data with useful graphic depictions. Thibos also calculates the blur strength, which is another index that can be used to characterize the effect on vision of the spherical and astigmatic components of the residual refractive errors.

Naeser and Hjortdal use polar analysis, as an alternative to vectorial analisys, in which they characterize any astigmatic value by 2 polar values that are separated by 45 degrees. In a subsequent work, Naeser and Hjortdal extended their methodology to trivariate analysis, which provides a 3-dimensional depiction that displays both polar values and the spherical equivalent ${ }^{(15)}$.

\section{Optical and physiological effects of ocular astigmatism}

Optical effects of ocular astigmatism are blur and distortion ${ }^{(7)}$. Astigmatism of as little as $0.75 \mathrm{D}$ may leave a patient symptomatic ${ }^{(12-13)}$. Blur is the lack of point focus and altered shape of the retinal image caused by the astigmatism. Distortion is the altered shape of objects caused by unequal magnification of the retinal image in the various meridians ${ }^{(7)}$.

\section{Treatment options}

Perhaps the most challenging aspect of astigmatism surgery involves the determination of the quantity and exact loca- 
tion of the cylinder that is to be corrected ${ }^{(12,22,23)}$. Unfortunately, preoperative measurements (keratometry, refraction, and corneal topography) do not always correlate. Lenticular astigmatism may account for some of this disparity, particularly in cases where there is a wide variance between refraction and corneal measurements; however, some discrepancies are likely caused by the inherent shortcomings of traditional measurements of astigmatism. Standard keratometry, for example, measures only two points in each meridian at a single optical zone of approximately $3 \mathrm{~mm}$. Corneal topography can be very helpful when refraction and keratometry do not agree, and it is increasingly becoming the overall guiding measurement on which the surgical plans are based ${ }^{(12)}$.

Posterior corneal astigmatism contribution to total corneal astigmatism is gaining interest, in recent years, due to increasing number of cases of unintended astigmatism under or overcorrections ${ }^{(24-25)}$.

\section{a) Incisional approach}

Incisional surgery creates gaping of the wound, addition of tissue in the incision, and elongation of the radius of curvature with subsequent flattening of the central cornea along the surgical meridian. Surgically induced astigmatism following tangential and arcuate incisions is characterized by coupling, by which an astigmatic change in one meridian is followed by a similar change in the orthogonal meridian with no net change in spherical equivalent refraction. Tight sutures will flatten the tissue around the incision with an initial steepening of the central cornea. Sutures have no long-time effect on astigmatism and an initial with-the-rule astigmatism is followed by against-the-rule decay after superior sutured cataract incisions. Surgically induced astigmatism after incisional surgery is predominantly influenced by wound length and placement, while patient age, preoperative astigmatism, and intraocular pressure play minor roles. Ablational laser surgery does not generate a coupling effect, and the spherical effect of ablation for astigmatism must be taken into account ${ }^{(7)}$.

A viable and relatively simple way to decrease astigmatism is to manipulate the cataract incision to impact favorably pre existing astigmatism. This may be accomplished by first centering the incision on the steep corneal meridian (hence to be termed "on axis" technique) and then by varying its size and design, to affect a desired amount of wound flattening, and hence a decrease in cylinder. Such an approach, however, presents logistical challenges including movement around the surgical table, often producing awkward hand positions (12,26-28).

Opposite clear corneal incisions may also be used to address pre existing astigmatism ${ }^{(12,29)}$. In this technique, a second opposite penetrating clear corneal incision is placed over the steep meridian 180 degrees away from the main incision. This approach is technically simple and requires no additional instrumentation; however, a second substantial penetrating incision is now present, possibly increasing the risk of wound leak or even infection. In addition, single-plane beveled incisions are known to be less effective, for a given arc length, at flattening the cornea as compared with traditional perpendicular relaxing incisions ${ }^{(12)}$.

For the reasons mentioned above, both on axis and opposite clear corneal incisions techniques have largely been supplanted by the use of a consistent and astigmatically neutral phacoincision, typically placed temporally, for stability, and then adding supplemental limbal relaxing incisions (LRI) ${ }^{(12,30)}$. Such an approach has become the most popular way to manage astigmatism at the time of cataract surgery ${ }^{(12,31-39)}$. The use of LRI offer several advantages over astigmatic incisions placed within the cornea, at smaller optical zones, including less chance of caus- ing a shift in the resultant cylinder axis and a lesser tendency to cause irregular corneal flattening with irregular astigmatism. Technically, LRI are easier to perform and more forgiving than shorter and more central corneal astigmatic incisions ${ }^{(12,31)}$. Another important advantage gained by moving out to the limbus involves the coupling ratio, which describes the amount of flattening that occurs in the incised meridian relative to the amount of steepening that results 90 degrees away; paired LRIs (when kept at or under 90 degrees of arc length) exhibit a very consistent 1:1 ratio, and elicit no change in spherical equivalent refraction, obviating the need to make any change in implant power. Admittedly, these more peripheral incisions are less powerful, but are still capable of correcting up to $3.50 \mathrm{D}$ of astigmatism in the cataract-aged population. One must keep in mind that the goal is to reduce the patient's cylinder, without overcorrecting or shifting the resultant axis. Their stability may well be caused by the proximity of well-vascularized limbal tissue. Nonetheless, as with any surgical technique, potential complications exist, the most likely to be encountered is the placement of incisions on the wrong axis. When this occurs, it typically takes the form of a 90-degree error with positioning on the opposite, flat meridian. This results in an increase and likely doubling of the patient's pre existing cylinder ${ }^{(12)}$.

\section{b) Non-incisional approach}

A recent advance in cataract surgery was the introduction of toric intraocular lenses (IOL) for the correction of pre existing corneal astigmatism ${ }^{(40,46)}$. The use of toric IOL have been reported to be an effective method of reducing postoperative refractive astigmatism and spectacle dependence following cataract surgery (47). Rotational stability of toric IOL is an issue of major concern, once proper alignment is critical for compensating corneal cylinder, resulting in good uncorrected vision. Each degree of rotation causes an average loss of cylinder power of approximately $3 \%$; thus, when an IOL rotates 30 degrees there is no astigmatic correction, although there is a change of axis ${ }^{(44,46-55)}$. Articles comparing the use of toric IOL to other astigmatism reducing techniques, such as opposed clear corneal incisions ${ }^{(56)}$ or LRI ${ }^{(57)}$, are still scanty in number on literature. Slightly advantageous outcomes, favoring toric IOL have been reported ${ }^{(56,57)}$, but debate on which technique unequivocally offers better results is just at the beginning. Toric IOL may also be employed in conjunction to such techniques aiming further refractive improvements ${ }^{(38)}$.

Correction of unintentional residual ametropia may be achieved by excimer laser enhancement procedures. Such an approach exploits the advanced technology and exquisite accuracy of the excimer lasers ${ }^{(12,58)}$. Phacoemulsification wound healing, along with a stable refractive error, must be confirmed prior to enhancement procedures. Custom wavefront-guided ablations are particularly well suited in the scenario of a pseudophakic eye, because the dynamic lens component no longer exists. For a few cataract surgeons, excimer laser enhancements have become part of the routine preoperative discussion with patients ${ }^{(12)}$.

\section{Conclusion}

Due to the prevalence of pre existing corneal astigmatism among cataract patients and its effects on final visual acuity, it is demanding for the cataract surgeon to address astigmatism, by the time of phacoemulsifcation, effectively as possible. Although several astigmatism reducing techniques exist, LRI and toric IOL are the most often used methods. Both strategies show limitations, advantages and drawbacks inherent to their use. 


\section{REFERENCES}

1. Hida WT, Motta AF, Kara-José Junior N, Alves E, Tadeu M, Cordeiro $\mathrm{LN}$, et al. Comparison between OPD-Scan results and visual outcomes of monofocal andmultifocal intraocular lenses. Arq Bras Oftalmol. 2009;72(4):526-32.

2. Kara-Jose Junior N, Santhiago MR. [Aspherical IOLs: clinical evaluation and options]. Rev Bras Oftalmol.2009;68(3):175-9. Portuguese.

3. Kara-Junior N, Santhiago MR, Parede TR, Espindola RF, Mazurek MG, Germano R, et al. [Influence of cataract surgical correction on working perception]. Arq Bras Oftalmol.2010;73(6):491-3. Portuguese.

4. Gothwal VK, Wright TA, Lamoureux EL, Pesudovs K. Measuring outcomes ofcataract surgery using the Visual Function Index-14. J Cataract Refract Surg.2010;36(7):1181-8.

5. Alió JL, Agdeppa MC, Pongo VC, El Kady B. Microincision cataract surgery with toric intraocular lens implantation for correcting moderate and high astigmatism: pilot study. J Cataract Refract Surg. 2010;36(1):44-52.

6. Carvalho MJ. Correção do astigmatismo corneano com incisão relaxante limbar na cirurgia de catarata[tese].São Paulo: Universidade Federal de São Paulo;2003.

7. Naeser K. Assessment and statistics of surgically induced astigmatism. ActaOphthalmol. 2008;86 Suppl 1:5-28.

8. Bauer NJ, de Vries NE, Webers CA, Hendrikse F, Nuijts RM. Astigmatismmanagement in cataract surgery with the AcrySof toric intraocular lens. JCataract Refract Surg. 2008;34(9):1483-8.

9. Ferrer-Blasco T, Montés-Micó R, Peixoto-de-Matos SC, GonzálezMéijome JM, Cerviño A. Prevalence of corneal astigmatism before cataract surgery. J Cataract Refract Surg. 2009;35(1):70-5.

10. Guan Z, Yuan F, Yuan YZ, Niu WR. Analysis of corneal astigmatism in cataractsurgery candidates at a teaching hospital in Shanghai, China. J Cataract Refract Surg. 2012;38(11):1970-7.

11. Kohnen T.Astigmatism measurements for cataract and refractive surgery. JCataract Refract Surg. 2012;38(12):2065.

12. Nichamin LD. Astigmatism control. Ophthalmol Clin North Am. 2006;19(4):485-93. Review.

13. Wolffsohn JS, Bhogal G, Shah S. Effect of uncorrected astigmatism on vision. J Cataract Refract Surg. 2011;37(3):454-60.

14. Höfling-Lima AL,Moeller CT, Freitas D, Martins EN. Manual de condutas em Oftalmologia. São Paulo: Atheneu;2008.p. 724-5.

15. Koch DD. How should we analyze astigmatic data? J Cataract Refract Surg. 2001;27(1):1-3.

16. Alpins NA. A new method of analyzing vectors for changes in astigmatism. JCataract Refract Surg. 1993;19(4):524-33.

17. Alpins NA. New method of targeting vectors to treat astigmatism. J CataractRefract Surg. 1997;23(1):65-75.

18. Alpins N. Astigmatism analysis by the Alpins method. J Cataract Refract Surg.2001;27(1):31-49.

19. Alpins NA, Goggin M. Practical astigmatism analysis for refractive outcomes incataract and refractive surgery. Surv Ophthalmol. 2004;49(1):109-22.Review.

20. Thibos LN, Wheeler W, Horner D. Power vectors: an application of Fourieranalysis to the description and statistical analysis of refractive error. OptomVis Sci. 1997;74(6):367-75. Review.

21. Thibos LN, Horner D. Power vector analysis of the optical outcome ofrefractive surgery. J Cataract Refract Surg. 2001;27(1):80-5.

22. Kobashi H, Kamiya K, Igarashi A, Ishii R, Sato N, Wang G, et al. Comparison of corneal power, corneal astigmatism, and axis location in normaleyes obtained from an autokeratometer and a corneal topographer. J CataractRefract Surg. 2012;38(4):648-54.

23. Norrby S, Hirnschall N, Nishi Y, Findl O. Fluctuations in corneal curvaturelimit predictability of intraocular lens power calculations. J Cataract RefractSurg. 2013;39(2):174-9.

24. Koch DD, Ali SF, Weikert MP, Shirayama M, Jenkins R, Wang L. Contribution ofposterior corneal astigmatism to total corneal astigmatism. J Cataract RefractSurg. 2012;38(12):2080-7.
25. Ho JD, Liou SW, Tsai RJ, Tsai CY. Effects of aging on anterior and posteriorcorneal astigmatism. Cornea. 2010;29(6):632-7.

26. Amesbury EC, Miller KM. Correction of astigmatism at the time of cataract surgery. Curr Opin Ophthalmol. 2009;20(1):19-24. Review.

27. Lombardo A, Lindstrom RL. Astigmatic keratotomy: arcuate and transverse incisions for managing astigmatism. In: Hernderson BA, Gills JP. A complete surgical guide for correcting astigmatism: an ophthalmic manifesto. Thorofare: Slack;2003. p.87-96.

28. Borasio E, Mehta JS, Maurino V. Surgically induced astigmatism afterphacoemulsification in eyes with mild to moderate corneal astigmatism: temporalversus on-axis clear corneal incisions. J Cataract Refract Surg. 2006;32(4):565-72.

29. Qammar A, Mullaney P. Paired opposite clear corneal incisions to correct preexisting astigmatism in cataract patients. J Cataract Refract Surg. 2005;31(6):1167-70.

30. Hida WT, Motta AF, Inomata DL, Jales MQ, Facio Júnior AC, José Junior NK, et al. [Limbal relaxing incision or the more curved meridian incision associated to phacoemulsification with multifocal intraocular lens implant: three case reports]. Arq Bras Oftalmol. 2008;71(2):273-7. Portuguese.

31. Carvalho MJ, Suzuki SH, Freitas LL, Branco BC, Schor P, Lima AL. Limbalrelaxing incisions to correct corneal astigmatism during phacoemulsification. JRefract Surg. 2007;23(5):499-504

32. Arraes JC, Cunha F, Arraes TA, Cavalcanti R, Ventura M. [Limbal relaxing incisions during cataract surgery: one-year follow-up]. Arq Bras Oftalmol. 2006;69(3):361-4. Portuguese.

33. Coloma-González I, González-Herrera M, Mengual-Verdú E, HuesoAbancens JR.[Limbal relaxing incisions and cataract surgery: our experience]. Arch Soc EspOftalmol. 2007;82(9):551-4. Spanish.

34. Gills JP, Wallace R, Miller K, Fine HI, Friedlander M, McFarland M, et al.Reducing pre existing astigmatism with limbal relaxing incisions. In: Hernderson BA, Gills JP. A complete surgical guide for correcting astigmatism: an ophthalmic manifesto. Thorofare: Slack; 2003. p. 99-119.

35. Cristóbal JA, del Buey MA, Ascaso FJ, Lanchares E, Calvo B, Doblaré M. Effect of limbal relaxing incisions during phacoemulsification surgery based on nomogramreview and numerical simulation. Cornea. 2009;28(9):1042-9.

36. Ganekal S, Dorairaj S, Jhanji V. Limbal relaxing incisions duringphacoemulsification: 6-month results. J Cataract Refract Surg. 2011;37(11):2081-2.

37. Kamiya K, Shimizu K, Ohmoto F, Amano R. Evaluation of corneal biomechanicalparameters after simultaneous phacoemulsification with intraocular lensimplantation and limbal relaxing incisions. J Cataract Refract Surg. 2011;37(2):265-70.

38. Ouchi M, Kinoshita S. AcrySof IQ toric IOL implantation combined with limbalrelaxing incision during cataract surgery for eyes with astigmatism >2.50 D. JRefract Surg. 2011;27(9):643-7.

39. Muftuoglu O, Dao L, Cavanagh HD, McCulley JP, Bowman RW. Limbal relaxingincisions at the time of apodized diffractive multifocal intraocular lens implantation to reduce astigmatism with or without subsequent laser in situkeratomileusis. J Cataract Refract Surg. 2010;36(3):456-64.

40. Carey PJ, Leccisotti A, McGilligan VE, Goodall EA, Moore CB. Assessment oftoric intraocular lens alignment by a refractive power/ corneal analyzer systemand slitlamp observation. J Cataract Refract Surg. 2010;36(2):222-9.

41. Gills JP,Cherchio M. Using the toric intraocular lens in a complete astigmatism management orogram. In: Hernderson BA, Gills JP. A complete surgical guide for correcting astigmatism: an ophthalmic manifesto. Thorofare: Slack;2003.p.157-67.

42. Horn JD. Status of toric intraocular lenses. Curr Opin Ophthalmol. 2007;18(1):58-61. Review.

43. Ruíz-Mesa R, Carrasco-Sánchez D, Díaz-Alvarez SB, Ruíz-Mateos MA,Ferrer-Blasco T, Montés-Micó R. Refractive lens exchange with foldable toricintraocular lens. Am J Ophthalmol. 2009;147(6):990-6, 996.e1. 
44. Freitas GO, Carvalho MJ, Boteon JE. [Refractive lens exchange using SN60T5 AcrySof Toric intraocular lens in stage 2 keratoconus]. Rev Bras Oftalmol. 2011;70(5):296-9. Portuguese.

45. Hill W. Expected effects of surgically induced astigmatism on AcrySof toricintraocular lens results. J Cataract Refract Surg. 2008;34(3):364-7.

46. Ahmed II, Rocha G, Slomovic AR, Climenhaga H, Gohill J, Grégoire A, Ma J; Canadian Toric Study Group. Visual function and patient experience afterbilateral implantation of toric intraocular lenses. J Cataract Refract Surg. 2010;36(4):609-16.

47. Statham M,Apel A, Stephensen D. Comparison of the AcrySof SA60 sphericalintraocular lens and the AcrySof Toric SN60T3 intraocular lens outcomes inpatients with low amounts of corneal astigmatism. Clin Experiment Ophthalmol.2009;37(8):775-9.

48. Koshy JJ, Nishi Y, Hirnschall N, Crnej A, Gangwani V, Maurino V, et al Rotational stability of a single-piece toric acrylic intraocular lens. J CataractRefract Surg. 2010;36(10):1665-70.

49. Shah GD, Praveen MR, Vasavada AR, Vasavada VA, Rampal G, Shastry LR. Rotational stability of a toric intraocular lens: influence of axial length andalignment in the capsular bag. J Cataract Refract Surg. 2012;38(1):54-9.

50. Buckhurst PJ, Wolffsohn JS, Naroo SA, Davies LN. Rotational and centrationstability of an aspheric intraocular lens with a simulated toric design. JCataract Refract Surg. 2010;36(9):1523-8.

51. Entabi M, Harman F, Lee N, Bloom PA. Injectable 1-piece hydrophilic acrylictoric intraocular lens for cataract surgery: efficacy and stability. J CataractRefract Surg. 2011;37(2):235-40.

52. Cervantes-Coste G, Garcia-Ramirez L, Mendoza-Schuster E, VelascoBarona C. High-cylinder acrylic toric intraocular lenses: a case series of eyes withcataracts and large amounts of corneal astigmatism. J Refract Surg. 2012;28(4):302-4.
53. Ernest P, Potvin R. Effects of preoperative corneal astigmatism orientation onresults with a low-cylinder-power toric intraocular lens. J Cataract RefractSurg. 2011;37(4):727-32.

54. Wolffsohn JS, Buckhurst PJ. Objective analysis of toric intraocular lensrotation and centration. J Cataract Refract Surg. 2010;36(5):778-82.

55. Biancardi AL, Walsh A, Barreto RP, Crema AS. [Toric intraocular lens implantation for cataract and irregular astigmatism related to pellucid marginal degeneration: case report]. Rev Bras Oftalmol. 2012;71(6):400-2. Portuguese.

56. Mendicute J, Irigoyen C, Ruiz M, Illarramendi I, Ferrer-Blasco T, Montés-Micó R. Toric intraocular lens versus opposite clear corneal incisions to correctastigmatism in eyes having cataract surgery. J Cataract Refract Surg. 2009;35(3):451-8.

57. Mingo-Botín D, Muñoz-Negrete FJ, Won Kim HR, Morcillo-Laiz R, Rebolleda G, Oblanca N. Comparison of toric intraocular lenses and peripheral corneal relaxingincisions to treat astigmatism during cataract surgery. J Cataract Refract Surg. 2010;36(10):1700-8.

58. Vianna LM, Nascimento HM, Campos M. [LASIK retreatment with customized versus conventional photo-ablation using LADAR - Alcon]. Rev Bras Oftalmol. 2011;70(3):162-7. Portuguese.

\section{Corresponding author:}

Giuliano O. Freitas

ISO Olhos, R. Eduardo Marquez, 50

ZIP Code 38400-442 - Uberlandia (MG), Brazil

Phone: +55 (34) 3230-5050 - Fax: + 55 (34) 3230-5055

E-mail: gofreitas@ufmg.br 